\title{
Financial Constraints and Inventory Investment of Listed Non-Financial Firms in Nigeria
}

\author{
OBEMBE, O.B. (Ph.D) (Corresponding Author) \\ Department of Economics, Obafemi Awolowo University, Ile-Ife, Nigeria \\ Tel: 234-803-691-6208; 234-815-613-3880Ｅ-mail: f_obembe@yahoo.com
}

ARAWOMO, O.

Department of Economics, Obafemi Awolowo University

Ile-Ife, Nigeria

Afolabi, Babatunde

Afe Babalola University, Ado-Ekiti, Nigeria

Received: December 20, 2011

Accepted: January 3, $2012 \quad$ Published: March 1, 2012

doi:10.5430/bmr.v1n1p106

URL: http://dx.doi.org/10.5430/bmr.v1n1p106

This research benefitted from funding provided by Carolyn McClain Young for sponsorship of postdoctoral training of the corresponding author at Andrew Young School of Policy Studies, Atlanta GA, USA where a significant proportion of this study was prepared.

\begin{abstract}
Firms can experience financial constraints in periods when the monetary authority embarks on contractionary monetary policy. Firms with good internal sources of funds are usually not affected during this time, but those with poor internal sources of funds and coupled with high asymmetric information with lenders are expected to be financially constrained. The response of firms during this period has been of much concern to researchers. This study examined a sample of 76 quoted firms in the Nigerian Stock Exchange (NSE) to verify this hypothesis, using a system GMM method of econometrics, our result shows that financial constraints does not have any significant impact on inventory investment. The implication of this study is that, asymmetric information between borrowers and lenders may have little or no effect in the credit market in Nigeria.
\end{abstract}

Keywords: Financial constraints, Inventory, System GMM, Nigeria

\section{Introduction}

The impact of financial constraints on various aspects of firm behavior has received a renewed attention from researchers in the recent time. One key aspect of this behavior is inventory investment. This has largely commanded the attention of researchers owing to its significance at both microeconomic and macroeconomic levels. At the microeconomic level, Holt et al. (1960) developed a production-smoothing/buffer stock models of inventory behavior in which it was pointed out that, firms engage in inventory investment to stabilize their production in the face of fluctuating sales. Moreover, in periods of economic recession, firms were believed to find it much easier to adjust their inventory investment faster and much easier than fixed capital investment. At the macroeconomic level, the importance of inventory investment derives from its role in macroeconomic fluctuations, John Bates Clark 1898 said, "The modern world regards business cycles much as the ancient Egyptians regarded the overflowing of the Nile. The phenomenon recurs at intervals, it is of great importance to everyone, and natural causes of it are not in sight" Mankiw (2003). Investment spending comprising fixed capital and inventory spending has been found to be the most volatile component of the Gross Domestic Product (GDP), this component though not as large as consumption goes to add to the productive capital stock used in increasing output. Hence, much of the declines experienced in GDP in periods of economic recessions have been attributed to reduction in investment spending. Out of the total investment spending, Inventory is 
found to be about 1 per cent (Mankiw, 2003) but its volatility is the most remarkable which makes it extremely very crucial to the study of economic fluctuations.

Hornstein (1998) adduced three reasons for the increased attention on changes in the level of inventory investment. First, change in inventory investment account for a substantial fraction of changes in GDP. Second, current changes in inventory investment were assumed to convey useful information about the near-term future of the economy and lastly, there is a view that the inherent dynamics of inventory investment are destabilizing to the economy.

Recent attention on factors influencing inventory investment has focused on the role of financial constraints. Firms can undergo financial constraints especially in periods of economic recession when there is a contraction of credit by banks owing to contractionary monetary policy. During this period, asymmetric information between lenders and borrowers could lead firms borrowing funds at higher rate of interests if they are more bank-dependent.

The need to understand the monetary transmission mechanism therefore has elevated the study of the impact of financial constraints on inventory investment of firms to the frontier of economic discourse in the recent time.

Empirical evidences regarding the impact of financial constraints have been mixed. In the US, Kashyap et al (1994) in a cross sectional study did not find any evidence of the impact of liquidity constraint on inventory investment. However, in another study using a panel data for US firms, Choi and Kim (2001) found that liquidity constraint impacted negatively on inventory investment. However, Cunningham (2004) in a study of Canadian firms did not observe any significant differences in the sensitivity of inventory investment to cash flow of firms with asymmetric information from those without. Moreover, Benito (2005) in a study of UK and Spanish firms came out with a finding that financial effects associated with liquidity and borrowing ratio were estimated to be stronger in UK firms considered to be market-based than Spanish firms which were classified as bank-based. This was interpreted to mean that financial constraints did not have any significant impact on inventory investment since the impact was expected to be stronger among Spanish firms rather than the UK firms.

Empirical evidences on financial constraints and inventory investment has however been limited to studies in developed capital and money markets. In our opinion, there are no studies from the developing economies especially the sub-Saharan Africa and in particular Nigeria shedding light on this issue. Nigeria deregulated its financial system in 1997 and since then it has embarked on a market-driven approach to monetary policy. In the recent time, monetary policy has focused on inflation targeting with the aim of bringing inflation rate to a single digit. The primary objective of this study is thus to provide empirical evidence relating to the impact of financial constraints on inventory investment from Nigeria with a weaker institutional environment compared to those of the developed capital and money markets.

The remaining part of this paper is divided into four sections. The second section presents the theoretical framework, while the third section deals with the empirical background; section four presents the data analysis and results, while the last section presents the discussions, summary, conclusions and recommendations.

\section{Theoretical background/Literature Review}

\subsection{Theoretical Framework}

Economic theory explaining inventory behavior includes the Production Smoothing Model and the (S,s) inventory model. Hornstein (1998) explained that if a firm's sales are subject to changes over time while the marginal cost schedule is constant, then the firm can minimize cost by smoothing production. Inventories are reduced (increased) anytime sales exceed (fall short of) production. Production is hence made less volatile than sales and in this case sales tend to be negatively related to inventories. A firm with increasing marginal cost wants to use inventories to smoothing production irrespective of whether or not changes in sales are predictable. If on the other hand, changes in sales were random whereby firms decides on current production before level of sales are known, inventories are used as buffer stock by reducing the level of inventories in the face of unusually high level of demand thereby further reinforcing the negative relationship between inventories and sales. However, if firms were subjected to changes in marginal costs as against changes in the level of sales, then, the implications on inventory, production and sales are different. During periods of low marginal costs, the firms increases production and accumulate inventories. In this period, production is more volatile than sales, hence, a positive relationship between production and inventory is observed.

In the (S,s) model, it is believed that a seller orders goods from the producer while the ordering attracts a fixed cost. It is assumed that the marginal cost of ordering is constant and that sales are exogenous. Hence, ordering for a large quantity at a time is expected to lower the unit cost of ordering while ordering for a smaller quantity attracts a higher level of cost. This thus presents the seller with a trade-off option. Ordering for a large quantity will reduce the cost of ordering while at the same time the funds used for the large order could as well earned interest income if it was not tied down. Thus the seller is faced with a decision of determining an optimal quantity of inventory such that when inventory investment is 
reduced to a critical minimum level of ' $s$ ' investment is made to bring up the level of inventory to ' $\mathrm{S}$ '. In this case, the relationship between sales and inventories is unclear (Hornstein, 1998).

Our focus in this paper is not in testing the production smoothening nor (S,s) hypotheses, but in using their proposition to identify factors that influence inventory investment and then augment it with our financial constraint variables. Several studies have investigated the impact of financial pressure on firms' behavior. However, most of the studies were confined to the advanced economies.

\subsection{Empirical Literature}

Kashyap et al (1994) examined a micro data for 933 firms in the US. The study which focused majorly on 1981-1982 and 1975-75 recessions that was attributed to tight monetary policy documented that firms with limited or no access to public bond markets were significantly liquidity constrained. This finding was however found to be absent in 1970s and 1980s which coincide with periods of loose monetary policy regimes.

Carpenter et al (1995) also used a quarterly data for the US firms examined three financial constraint hypotheses which include bank lending, collateral and internal finance. The study found strong support for the existence of financing constraints arising from adverse selection and moral hazard problems prevailing in debt and equity markets which was attributed to asymmetric information between firms and suppliers of external finance. Investment was predicted to be primarily dependent on internal funds due to limited availability of debt.

In the UK, Guariglia examined the effect of financial constraints on 994 firms covering the period 1968 to 1991 . The firms were separated into financially constrained and unconstrained firms based on their coverage ratio, short term debt-to-sales ratio and net leverage ratio. Separate regressions were run for total inventory growth, work-in-progress inventory growth and raw material inventory growth. Findings from the study also confirmed the existence of a significant link between financial variables and inventory investment which were found to be much stronger in firms with weak balance sheets during periods of recessions and tight monetary policy.

Similarly, Bo et al. (2002) examined the effect of financial constraints on Dutch firms covering the period of 1984-1995 using the Lovell Model and augmented it with financial variables. The study documented that capital market imperfection was relevant in explaining inventory behavior. Financial constrained firms were found to respond much more sharply to cash flows than unconstrained firms.

In Spain, Benito and Hernando (2002) examined the responsiveness of various aspects of firm behavior to financial pressure. Their study covered the period of 1985-2000 and involved about 5000 firms. Financial pressure was found to exert a significant impact on fixed investment, employment, inventories and dividends. A negative and significant impact was recorded for inventory behavior which implied that companies respond in part by altering their level of inventories when there is an increase in borrowing costs.

Cunningham (2004) in a study of 166 Canadian firms however obtained a different results from those obtained from the US, UK and Dutch firms. The study estimated three separate models consisting of old and young firms, bond-rated versus unrated firms, large versus small firms. In each of the regressions, the latter groups of firms were expected to be more financially constrained. However, findings from the study did not provide support for the theoretical proposition. Hence, asymmetric information seems to exercise insignificant influence between lenders and borrowers in Canada.

A study emanating from a developing country, India by Saggar (2003) examined inventory investment behavior among 1800 Indian firms covering the period 1971/1972 and 1999/2000. The study documented that cash flow continued to impact significantly on inventory investment in the post reform period that began from 1992-93. This implied that external financing premium was believed to continually exist in spite of the emergence of alternative sources of financing for firms through the Stock Exchange.

A study by Ogun and Akinlo (2010) on the channel of monetary policy in Nigeria revealed that banks were a weak channel of monetary policy. However, there has not been any microeconomic evidence to document how firms respond to financial pressure in Nigeria most especially the inventory investment behavior. This study is hence initiated to examine how firms' inventory behavior responds to financial constraints brought about by strict monetary policy in Nigeria.

\section{Methodology}

\subsection{Model Specification}

Following Kashyap et al (1994), Guariglia (1999) and Benito (2005), we specify our model as follows: 
$\Delta \ln (I N V T)_{i t}=\alpha_{i}+\beta_{1} \Delta \ln (S L S)_{i t}+\beta_{2} \Delta \ln (S L S)_{i(t-1)}+\beta_{3} \ln \left(\frac{I N V T}{S L S}\right)_{i(t-1)}+\beta_{4} L Q T_{i(t-1)}+\beta_{5} B R T_{i(t-1)}+\beta_{6}\left(\frac{C F L}{K}\right)_{i(t-1)}+\beta_{7} D B T_{i(t-1)}+\gamma_{t}+\varepsilon_{i t}$

Where $i$ refers to companies, $i=1 \ldots N$, and $t$ refers to years, $t=1, \ldots, T: \Delta$ denotes the first difference, INVT refers to the real inventories, while $S L S$ refers to real sales; $\propto_{i}$ refers to the company-specific fixed effect controlling for unobservable time-invariant influences on inventory investment. Liquidity is measured by the ratio of liquid asset to capital cost, while our liquid asset is measured by current asset minus current liabilities. Our capital cost is the replacement cost of the fixed asset. The BRT is the borrowing ratio and it is measured as the ratio of interest payments to cash flow, while the cash flow is measured as the addition of profit after tax and depreciation charges. BRT is used as a measure of financial pressure in the work of Nickell and Nicolitsas (1999) in their study of employment, wage growth and productivity among UK firms.

The coefficients of $\beta_{1}$ and $\beta_{2}$ represents the short-run rate of responsiveness of inventory investment to sales growth. The coefficient of $\beta_{3}$ indicates the speed of adjustment of inventory investment towards the long run relationship between inventories and sales which is expected to be negative. The coefficient $\beta_{4}$ and $\beta_{5}$ are expected to be greater than zero to proof the existence of the liquidity effect, while the significance of the $\beta_{5}$ and $\beta_{7}$ coefficients are expected to justify the bank-dependent hypothesis.

\subsection{Sample selection}

This paper employs a panel data set covering 11 years of 76 listed non-financial firms quoted on the Nigerian Stock Exchange (NSE) from 1997 to 2007. This panel is about the largest panel of listed non-financial firms that has ever been assembled by various researchers to study firm behavior in Nigeria. The size of firms covered can be said to represent about 80 per cent of all quoted firms in the non-financial sector in terms of number, market capitalization and total assets. The period of study is based on availability of data to cover as many firms as possible. Some of the data points for some firms were not available due to the inability of the firms to provide the financial reports, however, we interpolated for such missing cases. The missing data points were not up to 10 per cent of the total number of observations.

\section{Data Estimation and Presentation of Results}

\subsection{Descriptive Statistics.}

The sample means of the main characteristics of the firm are presented in table 1 . The mean of real inventory growth rate is -0.08 , while the inventory sales ratio is 0.3018 . The negative value of inventory growth rate may be attributed to the volatile prevailing economic/political environment during the study period. The value of inventory to sales ratio seems to be very substantial which makes this study very relevant. The mean value of sales is $=\mathrm{N}=4305.9$ million $(\$ 26.91 \mathrm{~m})$, while the average real sales growth is -0.0164 . The negative average real sales growth also points to an indication of a weak manufacturing sector. The increase in actual sales figures may have resulted from arbitrary price increases by the manufacturers. The mean borrowing ratio is 0.8711 and bank debt ratio is 0.1357 , this indicates that the debt profile reflects a lack of dependence on bank loans. About 76 percent of the firms were in the manufacturing sector while the remaining 24 per cent were in the services, commercial and retail sector.

The relationship between inventory and sales is presented in figure 1. The figure is a cross plot of the level of log of inventories and log of sales of the sampled firms. The figure clearly shows that there is a strong positive correlation between the two variables. The scale of the graph suggests that a log-linear relationship with unit elasticity in the long run is expected. A pooled cross sectional regression analysis of inventories with respect to sales reveals a coefficient of $0.78(0.065)$ which goes to justify our error correction specification of order (1) in the model.

The time series variation in inventory investment and sales is presented in figure 2, this shows the relationship between mean inventory investment and growth in sales between 1997 and 2007. The figure shows that movement in growth in investment and sales are almost very similar. From the trend, it can reasonably be inferred that political conditions may play some roles on the growth of inventory and sales. For instance, Nigeria witnessed a political logjam since 1992 when the acclaimed freest election was annulled by the military regime which precipitated some uncertainty in the political and economic environment, this situation dovetailed till 1999 when a new civilian administration was sworn in. The figure shows a downward trend down till 1999 and 2000 before picking up in 2001. The growth could not be sustained again because in 2002/2003, Nigeria had to prepare for another election, what happened in 2001 after the successful transition of power seems to repeat itself again in 2005/2006 when a tremendous growth was recorded in inventory and sales investment. However, at the end of 2007, sales were already at a decline because the country will have to conduct election again and transfer power to another person. This figure may be a good pointer to the role of 
political uncertainty in firm behavior which was not accounted for in previous studies from developed countries but which is revealed in the developing country.

The relationship between mean inventory growth and liquidity of the firm is presented in figure 3 . The first observation from the graph is the prevalence of acute fluctuations in inventory and sales growth. This could be an indication of poor inventory management among the firms, which may be related to the uncertainty in the political environment. The figure also seems to depict that liquidity movement predate inventory investment by about one year and the two variables moved in similar directions all through the period.

The relationship between inventory investment and borrowing ratio is presented in figure 4 . This relationship reflects the financial burden of servicing debt for the mean company in each year, for the most part of the graph, the two variables can be said to move in opposite direction, it was much more pronounced in 2001 and 2004. The borrowing ratio reached its peak in 2001 and its lowest level in 2005, while the inventory growth reached its minimum point in 1999 and 2004. The inventory growth all through from 1998 up to 2005 was below zero, while the borrowing ratio was between 6 and 12 per cent.

\subsection{Econometric analysis}

The econometric result is presented in table 2. The dynamic fixed effects were estimated with the use of GMM system estimator proposed by Arellano and Bond (1995) and examined by Blundell and Bond (1998). Most our variable displays high level of autocorrelation as shown by $M_{l}$ in the result, however, the estimation method requires that the second-order correlation be absent which is displayed as $M_{2}$. The Sargan tests of instrument validity were also displayed alongside the Difference-Sargan statistic, which tests the validity of additional moment conditions.

In table 2, the two sales growth terms, the error correction and the liquidity terms were specified in column 1 . Our estimates find significant positive support for sales growth but not lagged sales growth. The sales growth coefficient is 0.286 with a standard error of 0.0934 . The coefficient of the error correction terms indicates an annual speed of adjustment to the long-run equilibrium of 47.0 per cent which was significant at 10 per cent level. Our result suggests a faster rate of adjustment in inventories compared to 33-36 per cent obtained by Bo (2001) for the Dutch firms and 27-30 per cent for the US firms as reported in Carpenter et al. (1994) and Benito (2005) where the speed of adjustment was found to be around 15 per cent. However, our result compares well with that of Saggar (2003) for the Indian firms which recorded between $30-46$ per cent.

Our result could be explained by the observation noted under the times series variation of inventory and sales in figure 1 . Causes of sharp fluctuations seems to be more political than economic, as soon as the political climate seems a little stabilized, firms may not have much difficulties in adjusting their inventories.

The liquidity effect came out with a negative but not significant sign; this was replaced with the cash flow term in column 2 and borrowing ratio in column 3, while column 4 considered the bank borrowing ratio. None of these variables recorded a significant impact on inventory investment. This goes to show that financial factors had no significant impact on inventory investment. This also may lend credence to our observation on the fluctuation of inventory investment which seems to coincide with periods of political change in Nigeria. Furthermore, our study may have provided a microeconomic verification of the findings by Ogun and Akinlo (2010) that bank channel of monetary policy was very weak in Nigeria.

\section{Conclusions}

This paper examined the inventory adjustment of firms in an emerging economy, Nigeria. This study was motivated by some issues. First, there has been little or no information about how firms in emerging markets adjusts their inventory investments, most of the studies on this important issue emanates from developed countries, more importantly, the ratio of inventory to sales which is around 30 per cent makes it an important issue to be studied. Furthermore, a cursory look at the trend of growth in inventory investment shows a highly volatile picture which suggests that management of inventory at the firm level still leaves much to be desired and hence suggest the need to understand the underlying factors behind the volatility.

This study is however much more concerned with the verification of the hypothesis that inventory investments were much more influenced by financial constraints such as liquidity or cash flow and bank debt. A contractionary monetary policy such as increase in reserve requirement of banks is expected to limit the credit creating ability of banks thereby reducing the amount of credit available to the firms. A firm with internal cash constraints will have no other means of financing its investment other than to result to the banks which make them susceptible to the adverse effects of increase in costs of loans. Given that a study in Nigeria has confirmed that bank was a weak channel of monetary policy, no study in our opinion has come up to confirm or reject their findings using microeconomic evidence. Our study has thus been 
able to confirm that financial constraints transmitted through the banks did not have a significant impact on inventory investment in Nigeria.

We need to exercise some caution however in generalizing this result for Nigeria in that the study is restricted to only the firms quoted on the stock exchange and particularly on those whose information could be collected. These firms usually are the most viable ones with some of them having foreign affiliations. Hence their status alone could be taken as enough information about the standing of the firms for the purpose of extending credit by financial institutions or bond market.

Our study thus differs from those conducted in developed countries such as UK and the United States where financial constraints were found to exercise a significant impact on inventory investments, however, the study lends support to the results obtained in Canada. The major limitation of our study is in the fact that no attempt was made to distinguish between firms that were bank-dependent from those that were not, this was due to lack of adequate information about access of the companies to the financial markets. However in our opinion, differentiating them will not alter our findings significantly.

\section{References}

Arellano, M and Bover, O. (1995). Another look at the instrumental-variable estimation of error-components models. Journal of Econometrics, 69(1), 29-52. http://dx.doi.org/10.1016/0304-4076(94)01642-D

Benito, A and Hernando, I. (2002). Extricate: Financial Pressure and Firm Behaviour in Spain. Banco de Espana-Servicio de Estudios. Documento de Trabajo no. 0227

Benito, A. (2005). Financial pressure, monetary policy effects and inventories: Firm-level evidence from a market-based and a bank-based financial system. Econometrica, 72(286):201-224

Blundell, R.W. and Bond, S. (1998). Initial conditions and moment restrictions in dynamic panel data models, Journal of Econometrics, 87, 11-143. http://dx.doi.org/10.1016/S0304-4076(98)00009-8

Bo, H. Gerard, K.R. Lensink, E. S. (2002). Dutch Inventory Investment: Are Capital Market Imperfections Relevant Relevant? Applied Economics, 34: 15-22. http://dx.doi.org/10.1080/00036840010025128

Carpenter, R., S. Fazzari and B. Petersen (1998). Financing constraints and inventory investment: a comparative study with high-frequency panel data. Review of Economics and Statistics, 80(4): 513-19. http://dx.doi.org/10.1162/003465398557799

Choi, W. G., Y. Kim (2003). Trade credit and the effects of macro- financial shocks: evidence from US panel data. International Monetary Fund Working Paper, No 03/127.

Cunningham R. (2004). Finance constraints and inventory investment: Empirical Tests with panel data. Working paper 2004-38, Bank of Canada, Ontario, Canada.

Guariglia, A. and Mateut S. (2006). Credit channel, trade credit channel, and inventory investment: Evidence from a panel of UK firms. Journal of Banking and Finance, 30(10): 2835-2856. http://dx.doi.org/10.1016/j.jbankfin.2005.11.002

Hornstein, A. (1998). Inventory investment and the business cycles. Federal Reserve Bank of Richmond Economic Quarterly, 84(2): 49-70.

Kashyap, A., O. Lamont and J. Stein (1994). "Credit conditions and the cyclical behavior of inventories." Quarterly Journal of Economics, 109(3)S, 565-92.

Mankiw G.W. Macroeconomics. $5^{\text {th }}$ edition. New Your, NY: Worth Publishers, 2003, p. 548.

Nickell, S. and Nicolitsas, D. (1999). How does financial pressure affect firms?, European Economic Review, 43(8): 1435-1456. http://dx.doi.org/10.1016/S0014-2921(98)00049-X

Ogun, T.P. and Akinlo, A.E. (2010). The Effectiveness of Bank Credit Channel of Monetary policy Transmission: The Nigerian Experience, African Economic and Business Review 8(2)

Saggar, S. (2003). Inventory Investment Behaviour-Evidence from a Panel of Indian Firms. Reserve Bank of India Occassiional Papers, 3(3) 
Table 1. Sample mean of the key variables, except for manufacturing and commercial sectors presented as ratios. (Sales are in Millions of Naira.)

\begin{tabular}{|l|l|l|l|}
\hline & & Mean & Standard Error \\
\hline$\Delta \ln (I N V T)$ & Inventory Growth & -0.0827 & 0.0188 \\
\hline$I N V T / S L S$ & Inventory/Sales & 0.3018 & 0.0131 \\
\hline$S L S$ & Sales & 4305.9 & 250.2 \\
\hline$\Delta \ln (S L S)$ & Sales-Growth & -0.0164 & 0.0165 \\
\hline$L Q T$ & Liquidity/Capital Stock & 0.4410 & 0.0840 \\
\hline$C F L / K$ & Cash Flow/Capital Stock & 0.1081 & 0.0236 \\
\hline$B R T$ & Borrowing Ratio & 0.8711 & 0.0673 \\
\hline$D B T$ & Bank Debt Ratio & 0.1357 & 0.0173 \\
\hline Manufacturing sector & & 0.76 & \\
\hline Commercial/services sector & & 0.24 & \\
\hline No. of companies & & 76 & \\
\hline No. of observations & & 836 & \\
\hline
\end{tabular}

Table 2. Inventory Investment by Listed Nigerian non financial firms

\begin{tabular}{|c|c|c|c|c|}
\hline$\Delta \ln I N V T_{i t}$ & (1) & (2) & (3) & (4) \\
\hline$\Delta \operatorname{lnSLS} S_{i t}$ & $\begin{array}{l}0.2857 \\
(0.0934)^{* * *}\end{array}$ & $\begin{array}{l}0.2884 \\
(0.0940)^{* * *}\end{array}$ & $\begin{array}{l}0.2864 \\
(0.0934)^{* * *}\end{array}$ & $\begin{array}{l}0.2981 \\
(0.0939)^{* * *}\end{array}$ \\
\hline$\Delta \ln S L S_{i(t-1)}$ & $\begin{array}{l}0.0026 \\
(0.0724)\end{array}$ & $\begin{array}{l}0.0027 \\
(0.0724)\end{array}$ & $\begin{array}{l}0.0029 \\
(0.0724)\end{array}$ & $\begin{array}{l}0.0008 \\
(0.0722)\end{array}$ \\
\hline $\ln (I N V T / S L S)_{(i t-1)}$ & $\begin{array}{l}-0.4700 \\
(0.2688)^{*}\end{array}$ & $\begin{array}{l}-0.4697 \\
(0.2689)^{*}\end{array}$ & $\begin{array}{l}-0.4700 \\
(0.2710)^{*}\end{array}$ & $\begin{array}{l}-0.5305 \\
(0.2761)^{*}\end{array}$ \\
\hline$L Q T_{i(t-1)}$ & $\begin{array}{l}-0.0029 \\
(0.0147)\end{array}$ & & & \\
\hline$(C F L / K)_{i(t-1)}$ & & $\begin{array}{l}0.0081 \\
(0.0473)\end{array}$ & & \\
\hline$B R T_{i(t-1)}$ & & & $\begin{array}{l}0.0009 \\
(0.0283)\end{array}$ & \\
\hline$D B T_{i(t-1)}$ & & & & $\begin{array}{l}-0.1001 \\
(0.1082)\end{array}$ \\
\hline MANU & $\begin{array}{l}0.0789 \\
(0.1071)\end{array}$ & $\begin{array}{l}0.0711 \\
(0.1072)\end{array}$ & $\begin{array}{l}0.0753 \\
(0.1065)\end{array}$ & $\begin{array}{l}0.0789 \\
(0.1049)\end{array}$ \\
\hline Year effects & Yes & Yes & Yes & Yes \\
\hline$M_{1}$ (p-value) & 0.000 & 0.000 & 0.000 & 0.000 \\
\hline $\mathrm{M}_{2}$ (p-value) & 0.221 & 0.234 & 0.234 & 0.212 \\
\hline Instruments & $t-3, \ldots t-5$ & $t-3, \ldots t-5$ & $t-3, \ldots t-5$ & $t-3, \ldots t-5$ \\
\hline Sargan (p-value) & 0.128 & 0.129 & 0.127 & 0.128 \\
\hline Difference-Sargan ( $\mathrm{p}$-value) & 0.201 & 0.196 & 0.257 & 0.186 \\
\hline No. of firms & 76 & 76 & 76 & 76 \\
\hline No. of observations & 684 & 684 & 684 & 684 \\
\hline
\end{tabular}




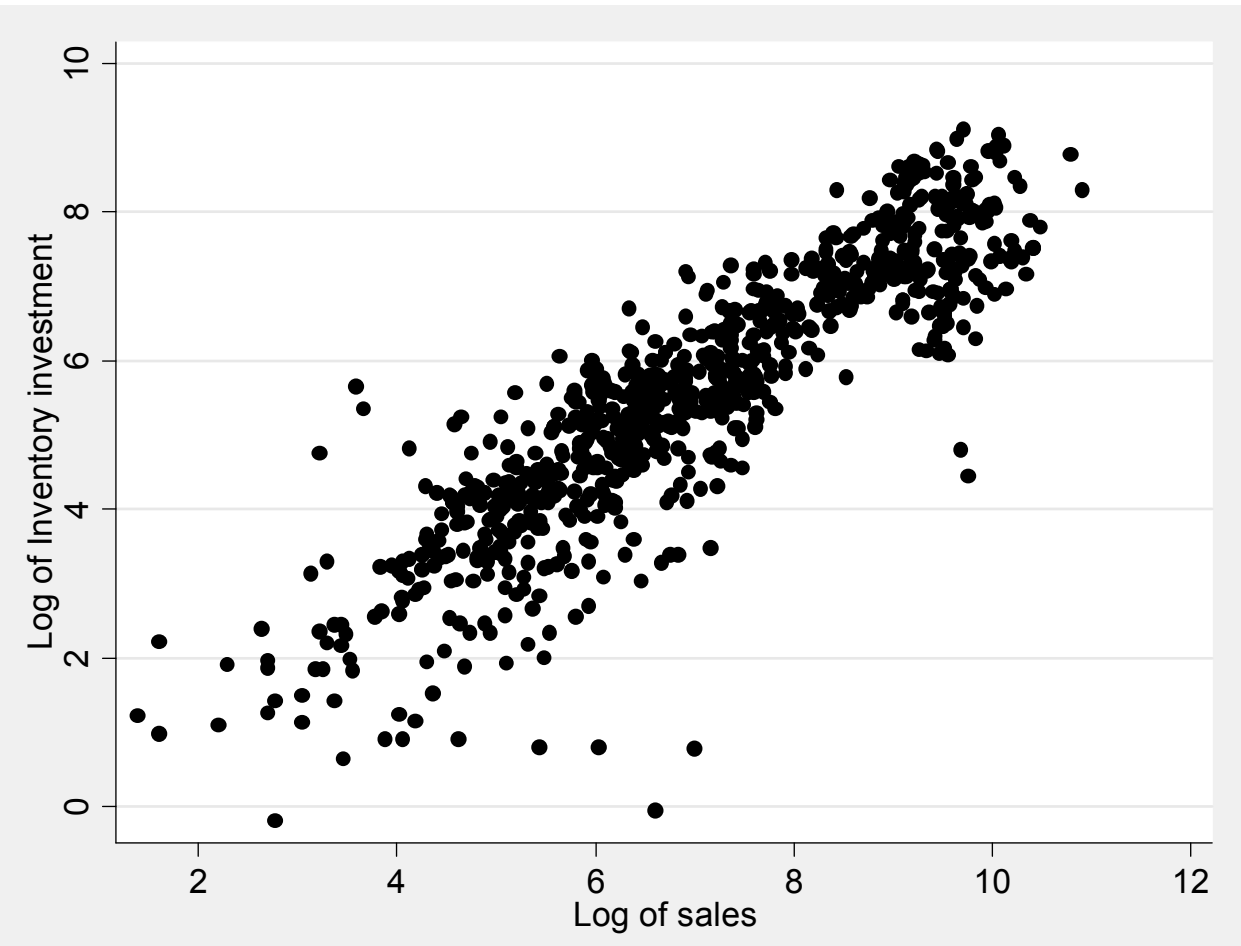

Figure 1. Relationship between Log of real inventories and Log of real sales

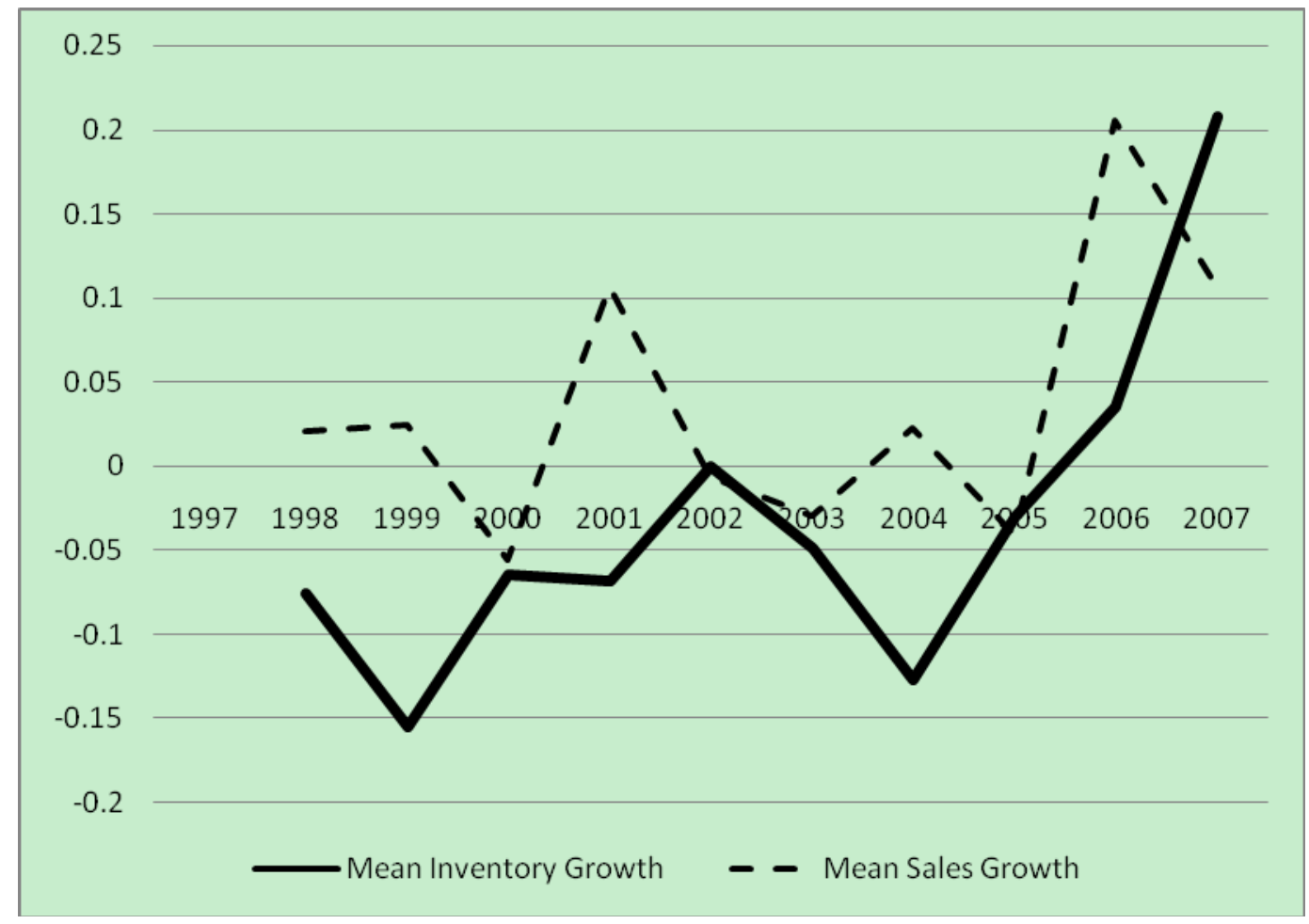

Figure 2. Growth in Mean of Inventory and Sales 


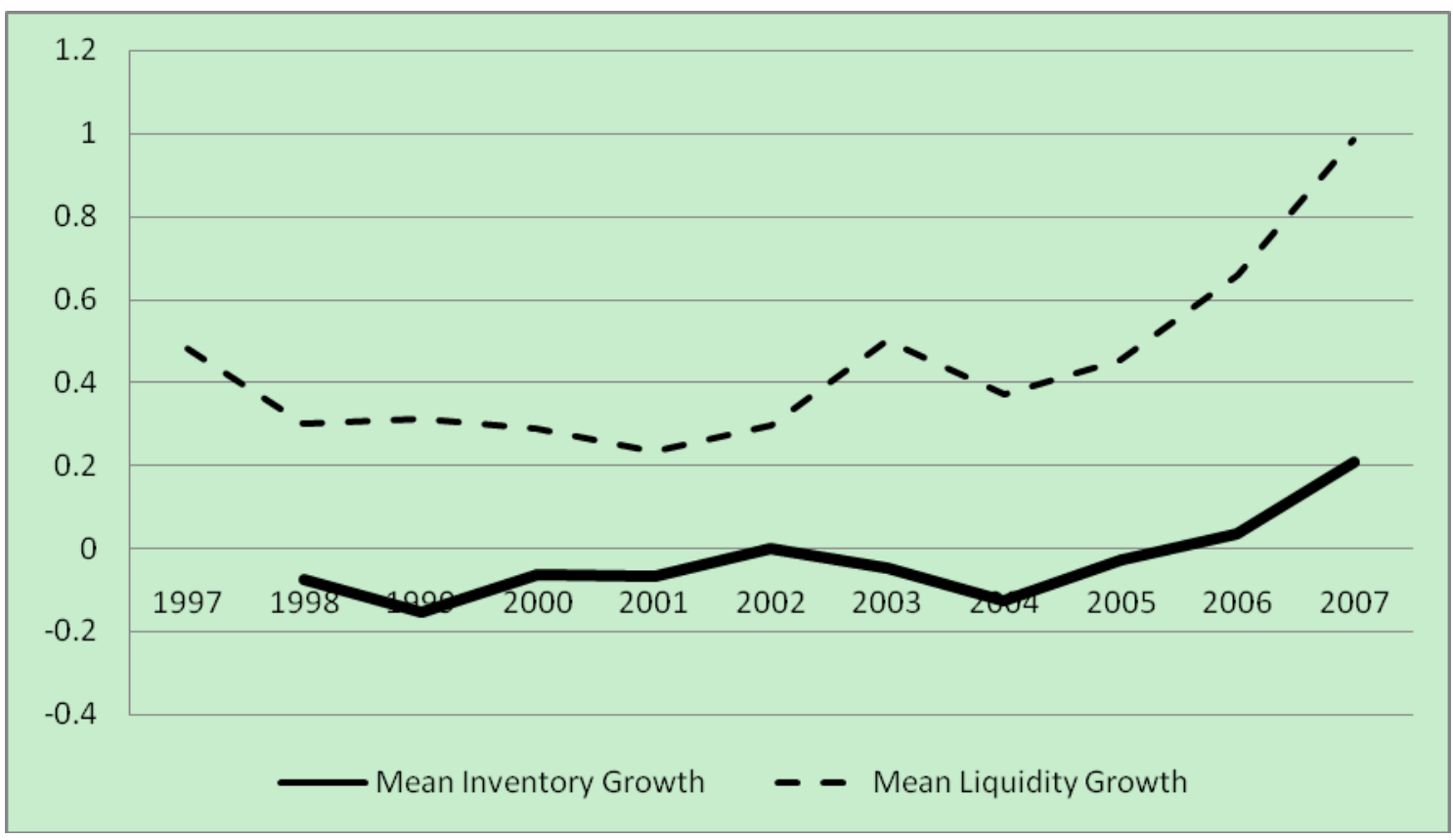

Figure 3. Inventory Growth and Liquidity

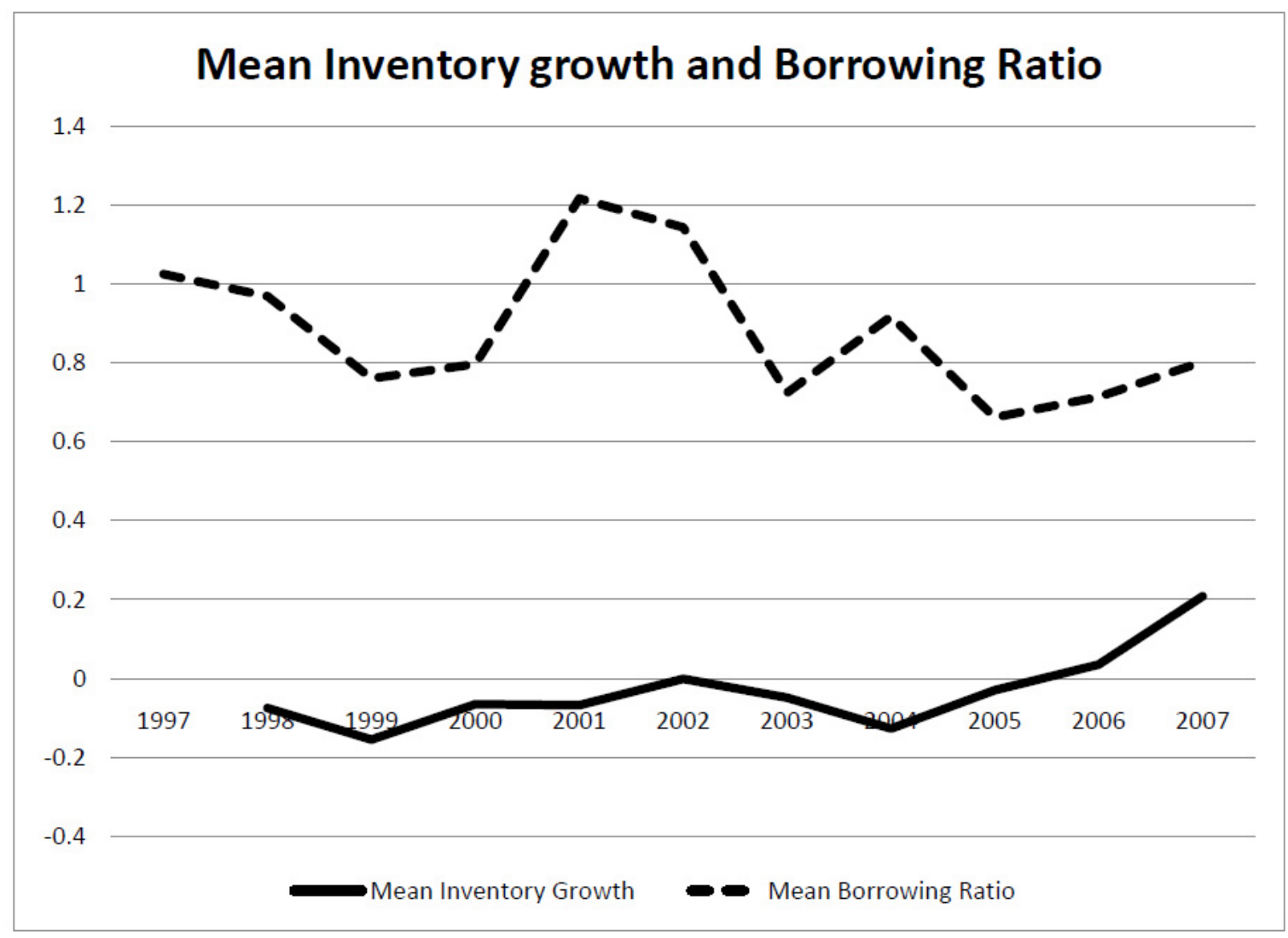

Figure 4. Mean Inventory growth and Borrowing Ratio 